\title{
Anti-cancer activity of new benzyl isoquinoline alkaloid from Saudi plant Annona squamosa
}

\author{
Adel M. Al-ghazzawi ${ }^{*}$ (D)
}

\begin{abstract}
Two alkaloids, belonging to benzylisoquinoline alkaloids, were isolated from Annona squamosa. One of these alkaloids, 6, 7-dimethoxy-1-(a-hydroxy-4-methoxybenzyl)-2-methyl-1, 2, 3, 4-tetrahydroisoquinoline, was isolated for the first time from natural sources, while, the alkaloid, Coclaurine was known in Annona squamosa L. Moreover, the isolated alkaloids tested for the anti-cancer activities on various cell lines (HepG-2, MCF-7, and HCT-116).
\end{abstract}

Keywords: Annona squamosa, Annonacea, (6, 7-dimethoxy-1-(a-hydroxy-4-methoxybenzyl)-2-methyl-1, 2, 3, 4-tetrahydroisoquinolin, Coclaurine

\section{Introduction}

Annona L. belongs to the family Annonaceae which is a large family comprising about 135 genera and more than 2500 species distributed mainly in tropical and subtropical regions [1-3]. Annona genus includes approximately 162 species of trees, shrubs and, rarely lianas [4]. Some species of Annona are of economic importance because of their edible fruits and medicinal properties, like Annona squamosa (sugar apple), Annona muricata (soursop), Annona reticulata (custard-apple) and Annona cherimola (cherimoya) [2]. Only one of Annona genus Annona squamosa was reported in Saudi Arabia [4]. Annona squamosa small tree, 2-3 m tall. Leaves without stipules, petiolate, alternate, lanceolate to elliptic-oblong, $8-13 \times 3-6 \mathrm{~cm}$, entire. Flowers solitary or in clusters of $2-4$, arising opposite the leaves, borne on a recurved pedicel. Perianth segments in $3 \mathrm{~s}$. Narrowly triangular, green to yellowish brown. Stamens were numerous. Carpels united into a fleshy mass in fruit. Seeds brown, surrounded by white, sweet pulp $[4,5]$.

Traditionally, all parts of $A$. squamosa are used by different ethnic communities for the treatment of various chronic diseases such as cancerous tumors, insect bites and other skin complaints [5-8]. However, the seeds powder is toxic and used to kill head lice and fleas $[5,9]$. The leaves used for a long time as ant- diabetics, antiulcer, anti-depressants, anti-inflammatory, antimicrobial and antifungal [10-15]. It has also used as Immunomodulatory and hepatoprotective $[5,9,16]$. Also, it used as fertility control [17].

Constituents of Annona squamosa have chemical compounds approximately belongs to all natural products compounds steroid, terpenoids, glycoside, alkaloid, flavonoid saponin and phenolic compounds $[5,9,16]$.

All previous study done on the anti-cancer activity of $A$. squamosa were dealing with the crude extract that contain all chemical constituents of A. squamosa or with non-alkaloidal parts especially acetogenin $[18,19]$. Because of there are several natural products have which have anti-cancer activity contain $\mathrm{N}$-atom in there skeleton reported in literature [20-22] and no previous study dealing with the anticancer activity of alkaloids part of $A$. squamosa, so in this research, we isolate some pure alkaloids from this plant also, we study the anti-cancer activity of the isolated alkaloids. 


\section{Results and discussion}

\section{Chemical analysis of Annona squamosal}

Chemical investigation of alkaloidal part of A. squamosa from Saudi origin resulted in the isolation of two benzylisoquinoline alkaloids, namely6, 7-dimethoxy-1( $\alpha$-hydroxy-4-methoxybenzyl)-2-methyl-1, 2, 3, 4-tetrahydroisoquinolin.1 and Coclaurine 2 (Fig. 1). The first one isolated for the first time from nature, while coclaurine were isolated before from $A$. squamosa.

\section{Structure elucidated for the isolated compounds}

6, 7-dimethoxy-1-(a-hydroxy-4-meth oxybenzyl)-2-methyl-1,

\section{2, 3, 4-tetrahydroisoquinolin (I)}

The ${ }^{1} \mathrm{H}-\mathrm{NMR}$ of compound (I) (Table 1 , see Additional file 1 ) shows two doublets in the aromatic region each one integrating for two protons which indicates parasubstituted benzene ring. The first doublet resonates at $\delta=7.028 \mathrm{ppm}(\mathrm{J}=10.5 \mathrm{~Hz})$ assigned for $2^{\prime}$ and $6^{\prime}$ while; another doublet appears at $\delta=6.838 \mathrm{ppm}(\mathrm{J}=10.5 \mathrm{~Hz})$ assigned for $3^{\prime}$ and $5^{\prime}$. Also, two singlet appears at $\delta=6.838 \mathrm{ppm}$ and $\delta=6.649 \mathrm{ppm}$ assigned for $\mathrm{H}-5$ and $\mathrm{H}-8$ respectively. The down-filled shift of $\mathrm{H}-8$ due

Table $1{ }^{1} \mathrm{H}$ and ${ }^{13} \mathrm{C}$ NMR spectroscopic data for 1 and 2

\begin{tabular}{|c|c|c|c|c|}
\hline \multirow[t]{2}{*}{ No. } & \multicolumn{2}{|l|}{$1^{a}$} & \multicolumn{2}{|l|}{$2^{b}$} \\
\hline & $\delta_{c}$ type & $\delta_{H}$ mult. $(J)$ & $\delta_{c}$ type & $\delta_{H}$ mult. $(J)$ \\
\hline 1 & 77.230 & 5.610 br s & 55.157 & $4.427 \mathrm{~m}$ \\
\hline 3 & d & $3.00-4.00 \mathrm{~m}$ & 38.95 & $3.35,3.25 c$ \\
\hline 4 & 29.715 & $3.00-4.00 \mathrm{~m}$ & 24.88 & $2.962,2.858 \mathrm{~m}$ \\
\hline $4 a$ & d & - & 122.72 & - \\
\hline 5 & 111.109 & $6.849 \mathrm{~s}$ & 115.35 & $6.727 \mathrm{~s}$ \\
\hline 6 & 147.196 & - & 147.05 & - \\
\hline 7 & 149.079 & - & 144.81 & - \\
\hline 8 & 110.966 & $6.649 \mathrm{~s}$ & 11.85 & $6.563 \mathrm{~s}$ \\
\hline $8 a$ & d & - & 124.72 & - \\
\hline a & $d$ & - & 38.79 & $\begin{array}{l}3.152,3.025 d d \\
(18,8)\end{array}$ \\
\hline $1^{\prime}$ & & - & 126.31 & - \\
\hline $2^{\prime}$ & 131.342 & $7.028 \mathrm{~d}(10.5)$ & 130.566 & $7.132 \mathrm{~d}(10)$ \\
\hline $3^{\prime}$ & 114.072 & $6.838 d(10.5)$ & 111.813 & $6.786 \mathrm{~d}(10)$ \\
\hline $4^{\prime}$ & 158.906 & - & 156.33 & - \\
\hline $5^{\prime}$ & 114.072 & $6.838 d(10.5)$ & 111.813 & $6.786 \mathrm{~d}(10)$ \\
\hline $6^{\prime}$ & 131.342 & $7.028 d(10.5)$ & 130.566 & $7.132 \mathrm{~d}(10)$ \\
\hline $6-\mathrm{OCH}_{3}$ & 55.455 & $3.884 \mathrm{~s}$ & 55.526 & $3.752 \mathrm{~s}$ \\
\hline $7-\mathrm{OCH}_{3}$ & 55.326 & $3.798 \mathrm{~s}$ & - & - \\
\hline $4^{\prime}-\mathrm{OCH}_{3}$ & 55.906 & $3.468 \mathrm{~s}$ & - & - \\
\hline $\mathrm{N}-\mathrm{CH}_{3}$ & 40.046 & $2.885 \mathrm{~s}$ & - & - \\
\hline
\end{tabular}

\footnotetext{
a Data were recorded in $\mathrm{CDCl}_{3} 500 \mathrm{MHz}(1 \mathrm{H})$ and $75 \mathrm{MHz}\left({ }^{13} \mathrm{C}\right)$

b Data were recorded in DMSO- $\mathrm{d}_{6}$ at $500 \mathrm{MHz}\left({ }^{1} \mathrm{H}\right)$ and $75 \mathrm{MHz}\left({ }^{13} \mathrm{C}\right)$

c Overlapped

d Not detected but appears in HMBC
}

to the inter hydrogen bonding between the hydroxyl group and the tertiary nitrogen which was confirmed by the IR spectroscopy. The hydroxyl methine proton resonates at $\delta=5.610 \mathrm{ppm}$ as broad singlet while the proton of hydroxyl group appears as a broad singlet at $\delta=5.171 \mathrm{ppm}$. The protons for $\mathrm{C}-3$ and $\mathrm{C}-4$ overlapped between 3-4 ppm. The spectrum shows two singlets integrating for 3 protons at $\delta=3.884 \mathrm{ppm}$ and $\delta=3.798 \mathrm{ppm}$ for methoxy group at C-6 and C-4' respectively moreover, the intermolecular hydrogen bonding between the hydroxyl group and the tertiary nitrogen can affect the protons of methoxy group at $\mathrm{C}-7$ which is downfield shifted to $\delta=3.468 \mathrm{ppm}$. The $\mathrm{N}$-methyl protons resonate as a singlet at $\delta=2.885 \mathrm{ppm}$. The ${ }^{13} \mathrm{C}$-NMR (see Additional file 1) shows 13 peaks, 7 of them for aromatic carbons, 3 peaks resonate at $\delta=55.455,55.326$ and $55.906 \mathrm{ppm}$ assigned for methoxy carbon, the $N$-methyl carbon appears at $\delta=40.046 \mathrm{ppm}$ also, the DEPT experiment confirms the presence of 5 methyl groups, four methines in aromatic region and 1 methylene carbon, too, one methine appears in upfield region resonate at $\delta=77.230 \mathrm{ppm}$.

The COSY experiment shows a good correlation between the $\mathrm{C}-3$ protons and the $\mathrm{C}-4$ protons, also, good correlations between para-substituted benzene ring protons. The most significant correlation is between $\mathrm{C}-1$ proton and $\mathrm{C}-\alpha$ proton (Fig. 2).

The chemical shifts of the different carbons of compound 1 assigned with the help of HMQC and HMBC experiments. The HMBC shows some good correlations between the methoxy protons and the aromatic carbons to which the methoxy groups are attached. Also, shows a good correlation between the protons of $\mathrm{C}-\alpha$ and $\mathrm{C}-1^{\prime}$, C-2', C-6'and C-8 (Fig. 3).

\section{Coclaurine}

The ${ }^{1} \mathrm{H}-\mathrm{NMR}$ of compound (I) (Table 1, see Additional file 1) shows two singlets resonate at $\delta=6.727 \mathrm{ppm}$ and $\delta=6.563 \mathrm{ppm}$ assigned for $\mathrm{C}-5$ and $\mathrm{C}-8$ respectively. Also, two doublets each integrating for 2 protons appears at $\delta=7.132 \mathrm{ppm}(\mathrm{J}=10 \mathrm{~Hz})$ and $\delta=6.786 \mathrm{ppm}$ $(\mathrm{J}=10 \mathrm{~Hz})$ indicating a para disubstituted benzene ring assigned for protons of ring $\mathrm{C}$. The $\mathrm{C}$-1protons resonate at $\delta=4.427 \mathrm{ppm}$ as multiplet while, the two protons of $\mathrm{C}-\alpha$ appears as two doublets at $\delta=3.152 \mathrm{ppm}(\mathrm{J}=18$, $8 \mathrm{~Hz})$ and at $\delta=3.025 \mathrm{ppm}(\mathrm{J}=18,10 \mathrm{~Hz})$. The first coupling due to geminal coupling between the $\mathrm{C}-\alpha$ while the second coupling with the $\mathrm{C}-1$ proton.

The ${ }^{13} \mathrm{C}$-NMR spectra (see Additional file 1) show 15 peaks for $17 \mathrm{C}$-atom indicting the presence of para disubstituted benzene ring in the compounds the DEPT experiments revealed this since the DEPT 135 and DEPT 90 


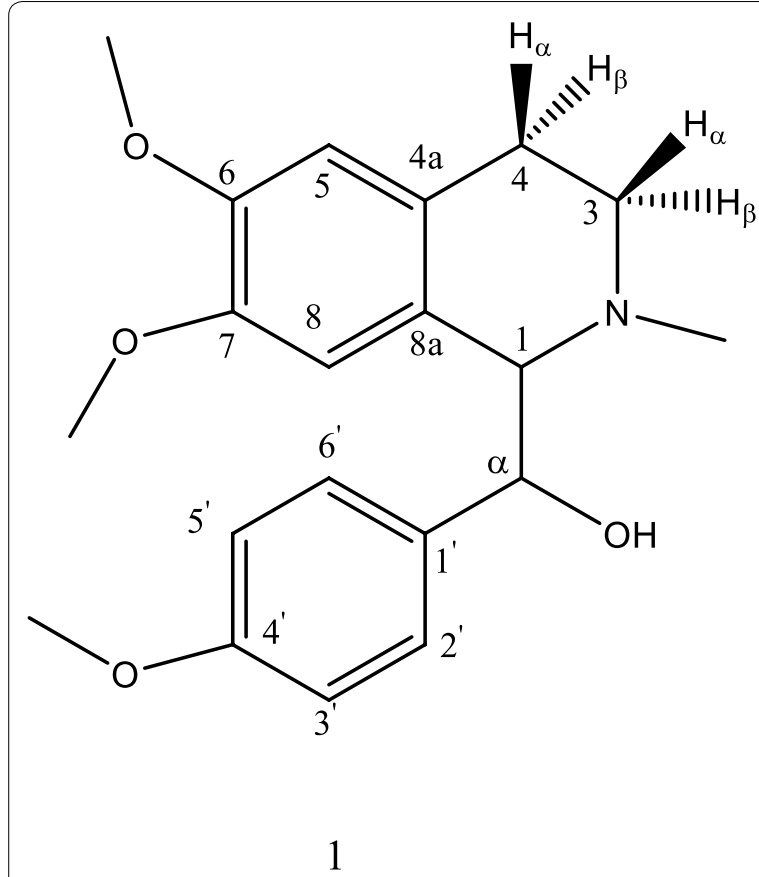

Fig. 1 Chemical structure of 1 and 2

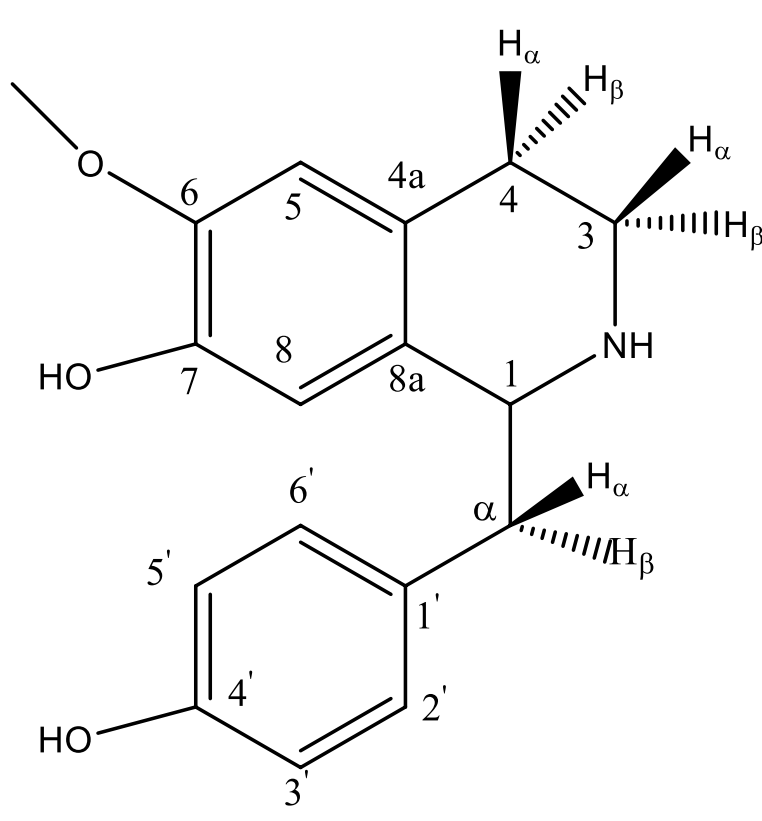

2
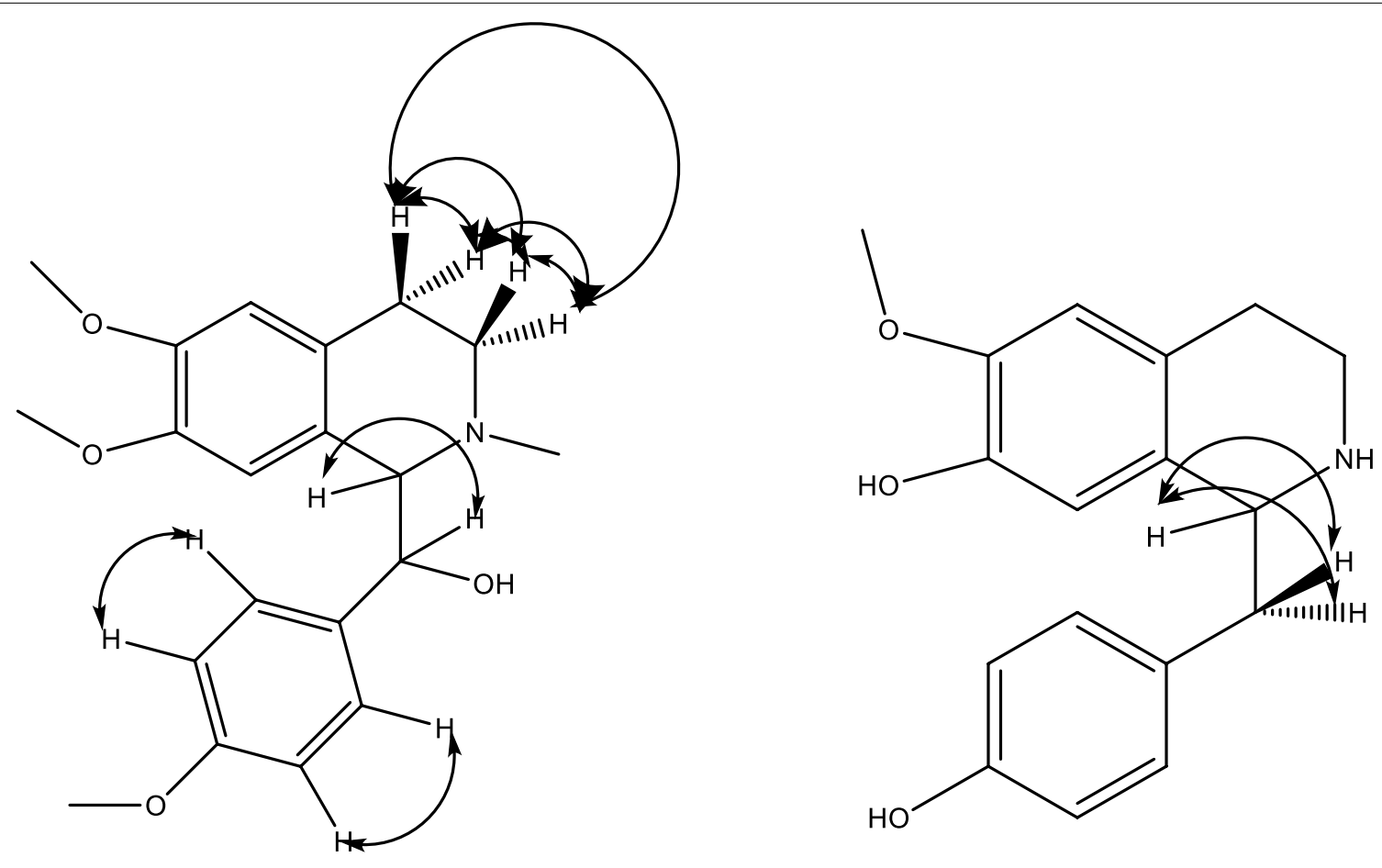

2

Fig. 2 COSY correlations of compounds 1 and 2 


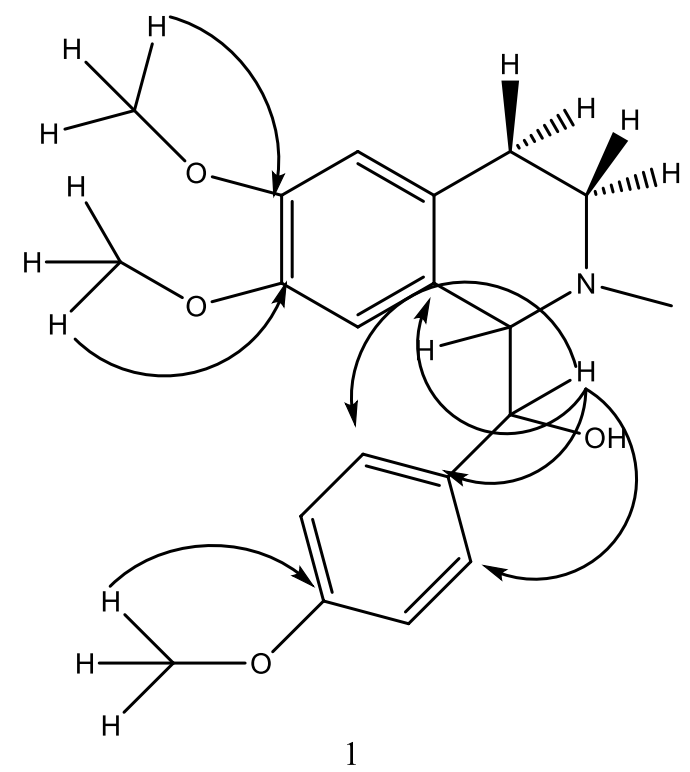

Fig. 3 HMBC correlations of compounds 1 and 2

shows four tertiary carbons and six quaternary carbons in aromatic region. Also, shows one methyl, two methylene and one methine carbons in aliphatic region.

The COSY experiments show good correlations between the two $\mathrm{C}-\alpha$ protons and $\mathrm{C}-1$ proton (Fig. 2).

The chemical shifts of the different carbons of compound 2 assigned with the help of HMQC and HMBC experiments. The HMBC shows good correlations between $\mathrm{O}-\mathrm{H}$ proton which resonate at $\delta=9.447 \mathrm{ppm}$ with C-4' and both of symmetric carbons $\mathrm{C}-3^{\prime}$ and $\mathrm{C}-5^{\prime}$. On the other hand, another $\mathrm{O}-\mathrm{H}$ proton shows a good correlation with $\mathrm{C}-7$ and $\mathrm{C}-8$ which indicate that the hydroxyl group is attached to C-7 rather than C-6. Also, one of the important correlations seen in $\mathrm{HMBC}$ spectra is the correlation between the $\mathrm{C}-1$ carbon and the proton of $\mathrm{C}-8$ and protons of $\mathrm{C}-\alpha$ (Fig. 3 ).

\section{Anti-cancer activity}

Anti-cancer activity of Annona plants reported in many documents, here, in this research, we study the anti-cancer activity of purely isolated alkaloids. In our study, we use three types of cancer cell line namely: Human Colon cancer cells (HCT116), Human Brest cancer cells (MCF7) and Human Liver cancer cells (HEPG-2). Table 2 shows the IC50 of Coclaurine and compound 2 against the mentioned cell line. The two isolated compounds gave an excellent activity on the three cell line; also, the two compounds show the most activity against HepG-2, but coclaurine shows a better activity than compound 2 this result on isolated compounds is in confident with structure-activity relationships studies of anti-cancer

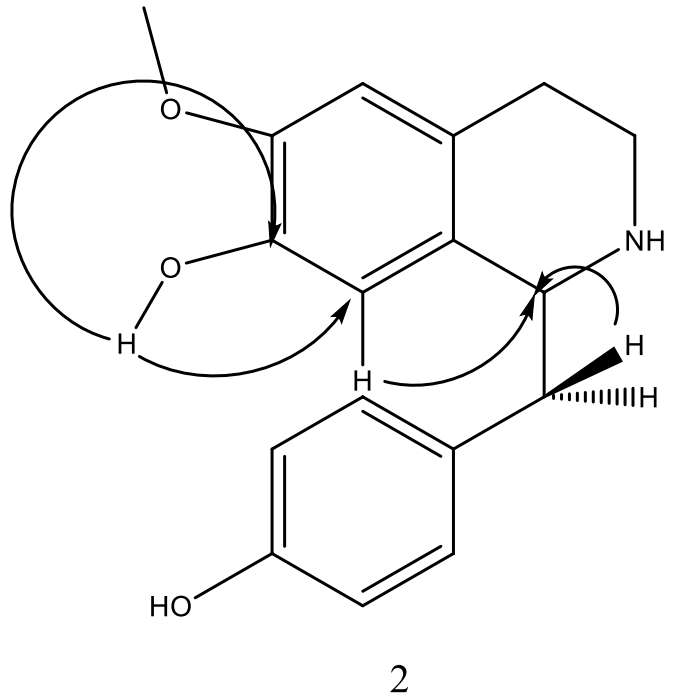

Table 2 IC50 of tested compounds

IC50 $\mu \mathrm{g} / \mathrm{mL}$ Tested extract (compound)

\begin{tabular}{lcll}
\cline { 2 - 4 } & $\begin{array}{l}\text { Colon cancer } \\
\text { cells (HCT116) }\end{array}$ & $\begin{array}{l}\text { Human brest } \\
\text { cancer cells } \\
\text { (MCF-7) }\end{array}$ & $\begin{array}{l}\text { Human liver } \\
\text { cancer cells } \\
\text { (HEPG-2) }\end{array}$ \\
\hline Coclaurine & 8.233 & 15.345 & 1.674 \\
Compound 2 & 12.344 & 21.586 & 5.195 \\
Doxorubicin & 0.8105 & 1.358 & 0.777 \\
\hline
\end{tabular}

activity of benzylisoquinoline alkaloids. The SAR studies show that the increase in the number of hydroxyl groups in the BIQ alkaloids increase the anti-cancer activity, on the other hand, methylation of nitrogen atom decrease the anti-cancer activity [22].

\section{Conclusion}

Chemical analysis of the alkaloidal part of A. squamosa, afforded two alkaloids belong to simple benzylisoquinoline alkaloid class. One of them is reported from natural sources for the first time.

Isolated alkaloids gave an excellent activity on Colon cancer cells (HCT116) and Human Brest cancer cells (MCF-7), which is confident with the reported structure-activity relationship of activity of benzylisoquinoline alkaloids on a cancer cell.

This result supports using the plant in folk medicine to treat cancer. 
Authors recommended to make total synthesis of the isolated alkaloids.

\section{Materials and methods Chemicals and materials}

All chemicals were purchased from Sigma-Aldrich. cell culture vessels were supplemented from Nunc Co. (Roskilde, Denmark). Human colon (HCT 116), Human liver (HepG-2) and Human breast (MCF-7) cancer cell lines were purchased from Vacsera (Giza, Egypt). Cells were maintained routinely in RPMI 1640 cell culture media supplemented with $1 \mathrm{mM}$ sodium pyruvate, $2 \mathrm{mM}$ L. glutamine, 100 units $/ \mathrm{mL}$ penicillin-streptomycin and $10 \%$ fetal bovine serum. Cells were incubated in a humidified, $5 \% \mathrm{CO}_{2}$ atmosphere at $37^{\circ} \mathrm{C}$.

${ }^{1} \mathrm{H}$-NMR spectra were recorded on a Bruker DPX$500 \mathrm{MHz}$ spectrometer with TMS as an internal standard. ${ }^{13} \mathrm{C}$-NMR spectra were recorded at $125.8 \mathrm{MHz}$ using the same instrument.

\section{Plant material}

The aerial parts A. squamosa, Annonaceae, were collected from Jizan region in Kingdome of Saudi Arabia in January 2017. The plant material was identified in biology department of King Khalid University.

Preparation of plant material:

The aerial parts of the plant were dried in the shade for 15 days then ground to get $6 \mathrm{~kg}$ fine powder. The powder was soaked in petroleum ether of 10 days for defatting then extracted thoroughly with ethanol four times each time needs 7 days later the ethanol was evaporated to get a $650 \mathrm{~g}$ residue.

\section{Preparation of alkaloidal extract}

The ethanol residue was dissolved in $5 \% \mathrm{HCl}$ until the $\mathrm{PH}=2$ of the solution and filtered, the precipitate which contains neutral material was kept for further fractionation, and the filtrate which provides the basic material was basify using $\mathrm{NH} 4 \mathrm{OH}$ solution, and the $\mathrm{PH}$ of the solution becomes around 8. After that, the solution was extracted with chloroform $500 \mathrm{~mL}$ three times the chloroform layer was evaporated to get $7.35 \mathrm{~g}$ of crude alkaloids which represent $0.123 \%$ of the dry plant.

\section{Chromatography of crude extract}

The crude alkaloids were subjected to silica gel column chromatography using a column packed in chloroform and polarity increasing using methanol till pure methanol was used. The fractions collected ( 60 fractions, $0.25 \mathrm{~L}$ each) were grouped according to their TLC behavior into six groups. Fraction III gave upon treatment of methanol a yellowish amorphous solid I (30 mg). Fraction V gave a dark brown amorphous solid when treated with methanol this solid were recrystallize by methanol to provide a solid white II $(50 \mathrm{mg})$.

\section{Physical and spectral data of isolated compounds from Annona sequamosa}

Compound I: Yellowish amorphous solid, IR $(\mathrm{KBr}) v_{\max }$ $\left(\mathrm{cm}^{-1}\right): 3393,2927,2852,1612,1514 .{ }^{1} \mathrm{H}-\mathrm{NMR}$ and ${ }^{13} \mathrm{C}-$ NMR data in Table 1.

Coclaurine: Compound II was crystallised from $\mathrm{MeOH}$ as white powder, m.p. $254-256 \mathrm{~d}{ }^{\circ} \mathrm{C},{ }^{1} \mathrm{H}-\mathrm{NMR}$ and ${ }^{13} \mathrm{C}$ NMR data in Table 1.

\section{Drug dose preparation}

$0.01 \mathrm{~g}$ of each pure compounds was diluted in $1 \mathrm{~mL}$ of (DMSO) dimethyl sulfoxide as a stock solution.

\section{Anti-cancer activity of isolated compounds from Annona sequamosa}

In the present study, SulphoRhodamine-B (SRB) assay had been chosen to detect the anticancer activity of isolated alkaloids. The anticancer activity of isolated alkaloids was tested against Human breast (MCF-7), Human colon (HCT 116), and Human liver (HepG-2) cancer cell lines. Cancer cells were exposed to a range of concentrations $(0.01$ to $100 \mu \mathrm{g} / \mathrm{mL})$ of alkaloids and incubated in $5 \% \mathrm{CO}_{2}$ humidified incubator at $37^{\circ} \mathrm{C}$ for $72 \mathrm{~h}$. Doxorubicin was used as a positive control. Cells were treated with the extracts for $72 \mathrm{~h}$ then; they were fixed with TCA (10\%) for $1 \mathrm{~h}$ at $4{ }^{\circ} \mathrm{C}$. To remove TCA cells were washed many times, then $0.4 \%$ SRB solution was used to stain cells in a dark place for $10 \mathrm{~min}$. Stained cells were washed with $1 \%$ glacial acetic acid. Finally, to dissolve SRB-stained cells, Tris- $\mathrm{HCl}$ was used. After drying overnight, the color intensity of remained cells was measured at $540 \mathrm{~nm}$ by Elisa.

\section{Statistical analysis}

The $\mathrm{IC}_{50}$ calculation was performed using Sigma Plot version 12.0

\section{Additional file}

Additional file 1: Figure S1. ${ }^{13} \mathrm{C}-\mathrm{NMR}$ spectra of 6, 7-dimethoxy-1-(ahydroxy-4-methoxybenzyl)-2-methyl-1, 2, 3, 4-tetrahydroisoquinoline. Figure S2. ${ }^{13} \mathrm{C}$-DEPT90 spectra of 6, 7-dimethoxy-1-(a-hydroxy-4methoxybenzyl)-2-methyl-1, 2, 3, 4-tetrahydroisoquinoline. Figure S3. ${ }^{13}$ C-DEPT135spectra of 6, 7-dimethoxy-1-(a-hydroxy-4-methoxybenzyl)-2methyl-1, 2, 3, 4-tetrahydroisoquinoline. Figure S4. ${ }^{1} \mathrm{H}-\mathrm{NMR}$ spectra of 6 , 
7-dimethoxy-1-(a-hydroxy-4-methoxybenzyl)-2-methyl-1, 2, 3, 4-tetrahydroisoquinoline. Figure S5. ${ }^{13} \mathrm{C}$-NMR spectra of Coclaurine. Figure S6.

${ }^{13} \mathrm{C}$-DEPT 90 spectra of Coclaurine. Figure S7. ${ }^{13} \mathrm{C}$-DEPT 135 spectra of Coclaurine. Figure S8. ${ }^{1} \mathrm{H}-\mathrm{NMR}$ spectra of Coclaurine

\section{Authors' contributions}

The author read and approved the final manuscript.

\section{Acknowledgements}

The author extend his appreciation to the Deanship of Scientific Research at King Khalid University for funding this work through General Research Project under grant number (G. R.P- 281-38).

\section{Competing interests}

The author declare no conflicts of interest.

\section{Publisher's Note}

Springer Nature remains neutral with regard to jurisdictional claims in published maps and institutional affiliations.

Received: 30 October 2018 Accepted: 16 January 2019

Published online: 04 February 2019

\section{References}

1. Leboeuf M, Cave A, Bhaumik PK, Mukherjee B, Mukherjee R (1982) The phytochemistry of the annonaceae. Phytochemistry 21(12):2783-2813

2. Rabêlo SV, Costa EV, Barison A, Dutra LM, Nunes XP, Tomaz JC, Oliveira GG, Lopes NP, Fátima Md, Santos C, da Silva Almeida JRG (2015) Alkaloids isolated from the leaves of atemoya (Annona cherimola $\times$ Annona squamosa). Revista Brasileira de Farmacognosia. 25:419-421

3. Teles MNO, Dutra LM, Barison A, Costa EV (2015) Alkaloids from leaves of Annona salzmannii and Annona vepretorum (Annonaceae). Biochem Syst Ecol 61:465-469

4. Alfarhan AAH, Al-Turki TA, Basahy AY (2005) Flora of Jizan region. Final report, vol 1

5. Saha R (2011) Pharmacognosy and pharmacology of Annona squamosa: a review. Int J Pharm Life Sci 2(10):1183-1189

6. Kadali VN, Pola SR, Sandeep BV (2016) Anti-cancer properties of plants in west Godavari district of Andhra Pradesh, India. Int J Pharmacogn 3(2):82-86

7. Vantitha V, Umadevi KJ, Vijayalakshmi K (2016) In vitro anti-proliferative effect of Annona squamosa (L.) leaf in the regulation of apoptotic genes in HEPG2 cell line. Int J Pharma Bio Sci 7(1):534-545
8. Chen Y, Chen Y, Shi Y, Ma C, Wang X, Li Y, Miao Y, Chen J, Li X (2016) Antitumor activityof Annona squamosa seed oil. J Ethno Pharmacol 193:362-367

9. Pandey N, Barve D (2011) Phytochemical and pharmacological review on Annona squamosa Linn. Int J Res Pharm Biomed Sci 2(4):1404-1412

10. Shirwaikar A, Rajendran K, Kumar CD, Bodla R (2004) Antidiabetic activity of diabetic rats. J Ethnopharmacol 91:171-175

11. Yadav CK, Singh N, Dev K, Sharma R, Sahai M, Palit G, Maurya R (2011) Anti-ulcer constituents of Annona squamosa twigs. Fitoterapia 82:666-675

12. Chavan MJ, Wakte PS, Shinde DB (2010) Analgesicandanti-inflammatory activity of Caryophyllene oxide from Annona squamosa L. bark. Phytomedicine 17:149-151

13. Jagtap UB, Bapat VA (2012) Antioxidant activities of various solvent extracts of custard apple (Annona squamosa L.) fruit pulp. Nutrafoods 11:137-144

14. Gupta RK, Kesari AN, Murthy PS, Chandra R, Tandon V, Watal G (2005) Hypoglycemic and antidiabetic effect of ethanolic extract of leaves of Annona squamosa L. in experimental animals. J Ethnopharmacol 99:75-81

15. Soni VK, Pathak M, Yadav DK, Maurya R, Sahai M, Jain SK, Bhattacharya SM (2013) Immunomodulatory constituents from Annona squamosa twigs provoke differential immune response in BALB/c mice. Curr Sci 104(9):1224-1230

16. Damasceno DC, Volpato GT, Sartori TCF, Rodrigues PF, Perin EA, Calderon IMP, Rudge MVC (2002) Effects of Annona squamosa extract on early pregnancy in rats. Phytomedicine 9:667-672

17. Zhou D, Sun LR, Feng F, Mo J, Zhu H, Yang B, He Q, Gan L (2013) Cytotoxic Diterpenoids from the Stem Bark of Annona squamosa L. Helv Chim Acta 96:656-662

18. Miao Y, Shi Y, Li F, Shan C, Chen Y, Chen J, Li X (2016) Metabolomics study on the toxicity of Annona squamosa by ultra-performance liquid chromatography high-definition mass spectrometry coupled with pattern recognition approach and metabolic pathways analysis. J Ethnopharmacol 184:187-195

19. Reddy CR, Reddy MD, Dilipkumar U (2014) Total synthesis of a pyrrole lactone alkaloid, longanlactone. Eur J Org Chem 28:6310-6313

20. Reddy CR, Dilipkumar U, Reddy MD, Rao NN (2013) Total synthesis and revision of the absolute configuration of seimatopolide B. Org Biomol Chem 11:3355-3364

21. Venkateshwarlu R, Chinnababu B, Ramulu U, Reddy KP, Reddy MD, Sowjanya P, Rao PV, Aravind S (2017) Synthesis and biological evaluation of (-)- kunstleramide and its derivatives. Med Chem Commun 8:394-404

22. Cui W, Iwasa K, Tokuda H, Kashihara A, Mitani Y, Hasegawa T, Nishiyama Y, Moriyasu M, Nishino H, Hanaoka M, Mukai C, Takeda K (2006) Potential cancer chemopreventive activity of simple isoquinolines, 1-benzylisoquinolines, and protoberberines. Phytochemistry 67:70-79
Ready to submit your research? Choose BMC and benefit from:

- fast, convenient online submission

- thorough peer review by experienced researchers in your field

- rapid publication on acceptance

- support for research data, including large and complex data types

- gold Open Access which fosters wider collaboration and increased citations

- maximum visibility for your research: over 100M website views per year

At BMC, research is always in progress.

Learn more biomedcentral.com/submissions 